\title{
EDITORIAL
}

\section{El desierto florido: alternativas para su aprovechamiento sustentable}

\author{
The flowering desert: alternatives for ite sustainable use
}

Felipe S. Carevic

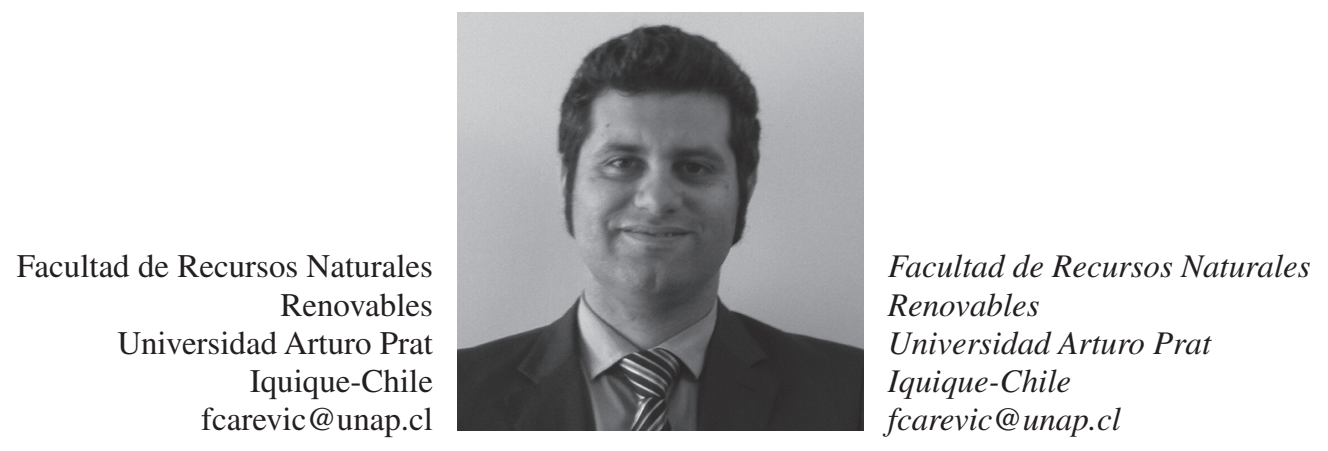

El fenómeno conocido popularmente como desierto florido ha arribado a nuestro norte con singular fuerza durante esta pasada primavera. Se trata de un fenómeno cuya periodicidad es escasa, registrándose en algunos casos una única vez al cabo del paso de una década. La definición propia de esta rareza natural es la aparición de vegetación de tipo anual sobre planicies o lomas -ubicadas entre la cordillera de la costa y la depresión intermedia- desprovistas de vegetación aparente. Uno de los primeros investigadores que dio a conocer este fenómeno a nivel científico fue curiosamente un extranjero de gran renombre internacional: Charles Darwin, quien en 1835 durante una visita al norte chico de nuestro país pudo describir con particular asombro la manifestación del desierto florido. Posteriormente, tan solo un lustro después de la expedición darwiniana, Claudio Gay logra ser espectador del fenómeno, donde describe más de una veintena de especies asociadas al desierto florido. Es precisamente este autor, junto al naturalista alemán Rodulfo Philippi, quienes describen y clasifican las más importantes especies asociadas al desierto chileno, con especial énfasis en la vegetación que logra imponerse durante el desierto florido.

En el plano biológico, las variables abióticas que inciden directamente en la manifestación de este fenómeno son las abundantes lluvias y el incremento de temperaturas durante el período invernal, estos se asocian directamente con la aparición del fenómeno
The phenomenon commonly called the flowering desert appeared in northern Chile with singular force this spring. This phenomenon is irregular, sometimes only occurring once per decade. This occasional event is the appearance of annual vegetation on plains and hills of the Coast Range and intermediate depression which are usually apparently devoid of vegetation. One of the first scientists who wrote about this phenomenon was curiously a well-known foreigner, Charles Darwin; during a visit to the "little north" in 1835 he observed and described with particular amazement the manifestation of the flowering desert. Only five years after Darwin's visit, Claudio Gay was witness to the spectacle; he described more than 20 new species associated with the flowering desert. Gay and the German naturalist Rodulfo Philippi were the two botanists who described and classified the most important species of the Chilean desert, with special emphasis on the species that appear in the flowering desert.

The abiotic variables that influence the manifestation of this phenomenon directly are abundant precipitations and warmer temperatures in winter; both are directly associated with the occurrence of the ENSO or El Niño 
del niño. En particular, durante este año el desierto del norte extremo anormalmente "húmedo". Es así como desde enero hasta noviembre del 2015 ciudades costeras como Iquique y Antofagasta que habitualmente registran un promedio de $0,6 \mathrm{y}$ $1,7 \mathrm{~mm}$ de precipitación, han presentado valores de 4,4 y 38,6 mm de agua caída. Mención aparte merece el hecho de las abundantes precipitaciones que se registraron en la comuna de Antofagasta, donde el agua caída durante 2015 superó 37 veces la sumatoria normal en un año, hecho que afectó directamente a la infraestructura urbana de la ciudad capital de la región. La región de Atacama tampoco estuvo ajena a las precipitaciones y localidades como Caldera triplicaron la sumatoria de precipitaciones normales en un año. No obstante, la otra condición sine qua non que debe prosperar para la aparición del desierto florido es el incremento térmico. Es así como según datos de la Dirección Meteorológica de Chile del 2015, en la región de Tarapacá el período otoñal comprendido entre marzo y mayo presentó una anomalía de $2^{\circ}$ Celsius por sobre las temperaturas medias mensuales, hecho que debió influir positivamente en la germinación de semillas depositadas en las lomas costeras de la región. Por su parte, en la región de Atacama la anomalía registrada durante mayo de $1{ }^{\circ} \mathrm{C}$ por sobre la media histórica parece ser la condición abiótica que influenció de mejor manera la aparición del fenómeno entre Copiapó y Vallenar.

A día de hoy, pocos estudios han destinado sus esfuerzos a conocer los mecanismos fisiológicos y ecológicos que rigen a estas poblaciones, principalmente por la escasa periodicidad con que se registra este fenómeno y a la extrema rapidez que caracteriza el período de germinación y floración en estas especies. A pesar de este hecho, los mayores estudios llevados a cabo se centran en taxonomía, logrando identificarse más de 50 especies en la actualidad. Durante el pasado año 2015 el fenómeno tuvo características inauditas, ya que la presencia de lomas con vegetación en el norte chileno se extendió incluso a la primera región. Es así como en la región de Tarapacá el desierto florido se manifestó de forma particular en los farellones costeros de Punta Gruesa y Chipana, con una dominancia absoluta de Nolana jafuelli y en menor medida de especies del género Leucocoryne. En la segunda región fue el sector de las lomas Los Arenales, al norte de Antofagasta, el área con mayor manifestación vegetacional. En la III Región especies del género Calandrinia, Leontochir y Cistanthe dominaron el árido paisaje durante el período previo al verano. A pesar de la singular belleza que este fenómeno biológico otorga en el escenario de aridez que enmarca el desierto, aún phenomenon. This year the "big north" (norte grande) hyperarid area of Chile had an abnormally wet year. Between January and November the coastal city of Iquique, which has mean annual precipitation of $0.6 \mathrm{~mm}$, received 4.4 $\mathrm{mm}$; while Antofagasta, whose annual mean is $1.7 \mathrm{~mm}$, recorded $38.6 \mathrm{~mm}$. This last figure is 37 times the annual average; it affected directly the urban infrastructure of this regional capitol. The Atacama region was also affected; Caldera had three times the normal annual precipitation. The other sine qua non condition for the flowering desert was also fulfilled; between March and May the Tarapaca region was $2{ }^{\circ} \mathrm{C}$ warmer than the normal mean monthly temperatures, which must have had a positive influence on the germination of seeds of the coastal hills of the region. In the Atacama region May was $1{ }^{\circ} \mathrm{C}$ warmer than the historical mean, providing an ideal positive influence for the appearance of the phenomenon between Copiapó and Vallenar.

Up to now few studies have attempted to understand the physiological and ecological mechanisms that rule these populations, mainly due to the low frequency of the phenomenon and the extremely short period of germination and flowering of these species. Most studies have been concentrated on taxonomy; more than 50 species have been identified so far. The phenomenon had unusual characteristics in 2015; even the coastal hills of the I region had vegetation. In the Tarapaca region there was a particular form of the flowering desert on the coastal cliffs of Punta Gruesa and Chipana, with dominance of Nolana jafuelli and lesser appearance of species of the genus Leucocoryne. The greatest manifestation in the II region was in the Los Arenales hills north of Antofagasta. The III region was dominated by species of the genera Calandrinia, Leontochir and Cistanthe in spring. In spite of the singular beauty that this phenomenon provides in the arid desert, there are still environmental measure that need to be corrected. The main one is to correct the scarce information given to visitors to avoid damage to these ephemeral populations. The greatest damage produced when the vegetation is present is from motorized vehicles that 
persisten algunas medidas ambientales a corregir. La principal de ellas radica en la escasa señalización otorgada a los visitantes para evitar el daño a estas efímeras poblaciones. Los mayores daños que suelen producirse al momento de manifestarse la aparición de la vegetación son el paso de vehículos motorizados por la zona y la utilización de estos espacios como lugares de esparcimiento en zonas no habilitadas. Es oportuno recordar -a modo de ejemplo- que especies del género Leontochir se encuentran actualmente clasificadas en peligro de extinción por el Ministerio de Medio Ambiente de nuestro país y este año constituyeron una parte importante de la biodiversidad vegetal del fenómeno.

Sin embargo, una de las mayores críticas que se suelen hacer a los municipios de las regiones del norte grande de Chile es la escasa inclusión de especies vegetales endémicas o nativas en el diseño de parques y espacios verdes de esparcimiento. Las especies presentes durante este tipo de fenómeno responden a pequeñas cantidades de agua y pequeñas anomalías en lo que respecta a las temperaturas ambientales, lo que las hace propicias para su incorporación como áreas verdes urbanas. Hasta el momento ninguna iniciativa contempló la recolección sostenible de semillas en las laderas de los cerros que presentaron vegetación con la finalidad de implementar programas de conservación de estas especies, mucho menos se procedió a proponer algún plan de utilización de estas especies en parques o plazas de las grandes ciudades del norte chileno, hecho que sin lugar a dudas contribuiría al uso eficiente del agua y a la conservación y conocimiento de estas especies vegetales por parte de la comunidad. A modo de ejemplo, los municipios de Glendale y Yuma en Arizona, han comenzado a generar planes de creación de áreas verdes urbanas con ayuda directa de los ciudadanos. Es así como se insta, por medio de proyectos ambientales de desarrollo urbano, a la colecta de semillas y posterior trasplante de plantas nativas a parques por parte de los habitantes de estas ciudades, con la finalidad educativa de conservar y conocer la biodiversidad local. A nivel gubernamental, es un hecho que con la creación de los servicios de biodiversidad y áreas protegidas en Chile en el corto plazo este tipo de iniciativas debieran transformarse no solo en un polo importante de conservación de ecosistemas frágiles como el desierto florido, sino que también en una poderosa herramienta ambiental de participación ciudadana orientada a conocer la flora nativa de la región en la que habitan los ciudadanos del norte de Chile.

Otro eje importante en el estudio de estos fenómenos de escasa ocurrencia debieran constituirlos pass through the areas and their use by people for picnics and recreation. It must be remembered that species of the genus Leontochir are currently classified as in danger of extinction by the Chilean Ministerio de Medio Ambiente; this year they formed an important part of the plant diversity in the flowering desert.

One of the strongest criticisms of the city governments of the regions of the norte grande of Chile is that they rarely consider endemic or native plants in the design of parks and recreation areas. The species that appear in the flowering desert respond to small quantities of water and small anomalies in temperature, which makes them propitious to include in urban green areas. So far no initiative has included the sustainable collection of seeds in the hillsides that flower in order to implement programs for the conservation of these species or proposed any plan to use these species in parks or plazas of the cities of northern Chile; this would undoubtedly contribute to the efficient use of water and the conservation and knowledge of these plant species by the communities. An example is being set by the cities of Glendale and Yuma in Arizona, USA; they have begun to generate plans to create urban green areas with direct citizen participation. Projects of urban environmental development such as these can include the collection of seeds and later transport of native plants to parks by the inhabitants of these cities, to teach them to conserve and know the local biodiversity. At the government level, with the creation of the services of biodiversity and protected areas in Chile in the short term, this kind of initiative should be not only an important conservation focus for fragile ecosystems such as the flowering desert, but also a powerful environmental tool with citizen participation oriented to know the native flora of the region they inhabit in northern Chile.

Another important focus in the study of these phenomena that occur occasionally should be the Chilean universities and research centers. There are few published scientific studies on the flowering desert. ¿What is the exact amount of precipitation necessary to generate it? ¿What 
las universidades y centros de investigación chilenos. En la mayoría de los registros de las revistas científicas de corriente principal son escasos los trabajos que desarrollen estudios pormenorizados respecto del fenómeno del desierto florido. ¿Cuánta es la cantidad exacta de precipitaciones necesarias para que se genere el fenómeno? o ¿Cuál es la temperatura que mejor se correlaciona con la germinación de semillas? son algunas de las preguntas que debiesen ser abordadas por el mundo científico, tomando en consideración el actual escenario de cambio climático que nos rige y el proceso de desertificación que actualmente sufren los ecosistemas áridos e hiperáridos en el planeta. Capítulo aparte merecen también los fenómenos que pueden producir el florecimiento de especies en zonas áridas e hiperáridas, ya que también se desconoce sobremanera el efecto del fenómeno del niño a nivel climático en zonas terrestres de nuestro país, ya que la atención principal se centra en los efectos dañinos del fenómeno en áreas marinas. Finalmente, es necesario destacar que no todas son brechas a abordar en el estudio del desierto florido, porque algunas iniciativas basadas en pequeños proyectos relacionados con educación ambiental se han desarrollado en la comuna de Vallenar, los que han tenido como objetivo dar a conocer algunas de las especies que se presentan durante este fenómeno a liceos y colegios de dicha comuna, como una manera de dar a conocer la biodiversidad endémica local de la zona. Debido a la belleza y singularidad de la vegetación que forma parte de este evento, surgen estas propuestas que pueden transformarse en un importante eje de conservación de estas especies, las que debieran formar parte activa de políticas locales y gubernamentales en el plano ambiental. temperature correlates best with seed germination? These are some of the questions that should be researched by the scientific community, taking into consideration the current scenario of climate change and the desertification process that currently affects the arid and hyperarid ecosystems of the planet. The phenomena that can produce flowering in arid and hyperarid zones are also little studied; the effect of the ENSO El Niño phenomenon is almost unknown in Chile, since most attention has been centered on the damage produced by this phenomenon in marine areas. Finally, it should be pointed out that there is not a complete lack of interest in the flowering desert, since some initiatives based on small projects related to environmental education have been developed in the community of Vallenar, whose objective has been to introduce some of the species of the flowering desert to students in grammar and high schools of this community as a way of introducing the local endemic biodiversity of the zone. Due to the beauty and singularity of the species that appear in the flowering desert these proposals arise that may be transformed into an important conservation focus for these species, which should form an active part of local and government environment policies. 